\title{
Om kravet på oskuld. En studie av flickors respektive pojkars föreställningar
}

\author{
MARIET GHADIMI
}

Ungdomars attityder till sexualitet är ett återkommande tema inom sexualitetsforskningen. Generellt instämmer ungdomar med utländsk bakgrund i större utsträckning i så kallade "oskuldsnormer", det vill säga normer som begränsar det föräktenskapliga sexuella handlingsutrymmet än ungdomar med svensk bakgrund. I denna artikel undersöks detta samband mer ingående samtidigt som det kontrolleras mot andra sociala bakgrundsfaktorer.

\section{Inledning}

En återhållsam inställning till föräktenskapliga sexuella relationer har haft offentligt stöd i Sverige fram till den så kallade "sexuella revolutionen" i slutet av 1960talet. I samband med att sex- och samlevnadsundervisningen blev obligatorisk i grundskolan år 1956 gav Skolöverstyrelsen sitt stöd till en återhållsam syn och uppmanade lärare att påpeka avhållsamhetens

Mariet Ghadimi, doktorand, Socialhögskolan, institutionen för socialt arbete, Stockholms universitet. positiva aspekter för ungdomar. Flera olika faktorer såsom utbyggnaden av välfärdstaten, sekulariseringen, kvinnans förändrade ställning och lagen om fri abort har bidragit till ett förändrat sexualmönster i samhället (Zetterberg 1969). Detta tillsammans med gratis preventivmedelsrådgivning och ungdomsmottagningar har influerat synen på ungdomssexualiteten som en allmänt accepterad företeelse (jmf. Lewin \& FuglMeyer 1998, Zetterberg1969). Numera är föräktenskapliga sexuella relationer allmänt accepterade bland både yngre och äldre (se ex. Jarlbro 1989, Helmius 1990).

En tolkning av ungdomars föreställningar 
kring sexualitet är att det delvis rymmer motsägelsefulla tendenser. Det finns tecken på ett öppnare förhållningssätt till sexualitet i ungdomsgrupper som uttrycks i bland annat en mer tillåtande attityd till sexuella relationer utanför etablerade heterosexuella förhållanden och större acceptans för homo- och bisexualitet. Samtidigt kan det urskiljas en tendens i motsatt riktning som kännetecknas av en traditionell syn på sexualitet främst bland ungdomar med utländsk bakgrund (se ex. Andersson 2003, Forsberg 2005). Även bland ungdomar inom olika frikyrkliga församlingar domineras den allmänna synen av att sexualiteten inte bör praktiseras utanför äktenskapet (Persson 2003). ${ }^{1}$

Det övergripande syftet i denna studie är att ta reda på ungdomars föreställningar om oskuldens särskilda betydelse för flickor respektive för pojkar samt att studera gemensamma mönster och skillnader utifrån elevernas kön och etniska bakgrund. Studien baseras på en enkätundersökning bland 1193 elever i årskurs sju till nio som företagits i fyra kommunala grundskolor. Enkätundersökningen ligger till grund för ett större forskningsprojekt där föreliggande artikel är en av flera studier kring ungdomars föreställningar och upplevelser av förhållande i skolan, hemmet och på fritiden. ${ }^{2}$

1 Ungdomar som ingår i Perssons studie har sin församlingstillhörighet inom olika pingstförsamlingar och Evangeliska Fosterlandsstiftelsen.

2 Enkätundersökningen ingår i projektet "Lärandets villkor för pojkar och flickor med tvåkulturell bakgrund" som är finansierat av Skolverket och utförs vid Institutionen för socialt arbete, Stockholms universitet. Se publicerade studier av Högdin, S. (2006).

\section{Tidigare studier om sexualitet}

\section{Respektabilitet och Kön}

Föreställningar om respektabilitet och på vilket sätt det är kopplat till sexualitet ser olika ut i olika samhällen. Det är viktigt för båda könen att bli respekterade, men för män är respektabiliteten inte kopplad till sexualiteten på samma sätt som den är för kvinnor (se ex. Ambjörnsson 2004, Skeggs 2000). ${ }^{3}$ I västerländska samhällen är individens autonomi i fokus, det är den personliga integriteten och inte en persons offentliga roll som är avgörande i frågor om respektabilitet. Dock bör sexuella relationer helst ske inom ett kärleksförhållande (Forsberg 2005). I traditionella samhällssystem, där föräktenskapliga sexuella relationer är starkt kritiserade, finns striktare föreställningar om respektabilitet. Sexualiteten betraktas oftast inte bara som en angelägenhet för den enskilde, utan är också en angelägenhet för hela familjen/släkten (Wikan 2005). Respektabilitetsnormer leder oftast till olika tolkningar och bemötanden av flickors respektive pojkars sexuella erfarenheter och förutsättningar. Oberoende av på vilket sätt normer kring respektabilitet fullföljs är den huvudsakliga ambitionen att

3 Beverly Skeggs myntade begreppet respectability (på svenska respektabilitet). Hon har studerat unga engelska arbetarklasskvinnor och skriver att de på grund av deras kläder, smink och stil ständigt blir bedömda och ifrågasatta av omgivningen. Kvinnorna "lyckas inte» leva upp till bilden av den "rätta» kvinnligheten, det vill säga den respektabla kvinnan och utpekas bland annat som smaklösa, påträngande och arbetarklass (se även Ambjörnsson 2004). 
kontrollera kvinnors sexualitet (Forsberg 2005).

Könsskillnader som framförallt begränsar flickors och unga kvinnors sexuella möjligheter är i större utsträckning styrande i länder med mer traditionella och könssegregerade samhällsstrukturer (se ex. Akpinar 1998, Mørck 2000, Okin 2002, Wikan 2005). Den kvinnliga sexualiteten och särskilt bevarandet av oskulden betraktas som en grundläggande och explicit markör för ärbarhet och heder (se ex. Delaney 1987, Eldén 2003, Forsberg 2005, Prieur 2004). Bekräftelsen att en ung kvinna är anständig och orörd har ett starkt symboliskt värde för familjens/ släktens anseende inför andra i bekantskapskretsen och/eller minoritetsgruppen (Akpinar 1998, 2003, Delaney 1987, Wikan \& Mitchell 2005). Särskilt gäller detta hennes sexuella beteende som via normgivande föreställningar om bland annat kyskhet i mer eller mindre utsträckning kan vara föremål för övervakning (Länsstyrelsen 2002:13, Länsstyrelsen 2004:4). Familjen/släkten anser sig berättigade och/eller förväntas att begränsa framförallt flickors handlingsutrymme för att förhindra ryktesspridning om att flickan kan ha mist sin oskuld och/eller för att få tillstånd ett passande giftermål (Eldén 2003, Jemteborn 2005, Schlytter 2004). Respektabilitetsnormer har också sin grund i religionen och i vissa länder reglerar den familjerättslagar (Darvishpour 1993, Farahani 2006, Fronk et al. 1999). Kvinnors sexualitet betraktas som farlig och förförande varför den är i behov av social kontroll (Awla 2005, Farahani 2006, Khader 1998).
Ungdomar som inte får ha pojkvän/flickvän eller inte får delta i skolans samlevnadsundervisning och andra skolaktiviteter (ex. klassresor) har uppmärksammats inom ramen för detta forskningsprojekt. Resultatet visar att en överhängande stor majoritet av dessa ungdomar är flickor med utländsk bakgrund (Högdin 2006).

Att flytta till ett nytt land kan innebära att individens föreställningar om sexualitet influeras av de dominerande normerna i det nya landet. Ahmadi (2003) menar att synen på ungdomssexualitet och oskuld är under förändring bland vuxna iranier. Det finns under vissa premisser mer acceptans för utomäktenskapliga sexuella relationer oavsett om det gäller pojkar eller flickor (Ahmadi 2003).

\section{Sexualitet, Kärlek och Könsskillnader}

Ungdomssexualitetsforskningen har kunnat visa att normer kring sexualitet ser olika ut för flickor och pojkar. Det finns explicit uttryckta normer som i viss utsträckning är lika för båda könen och som används vid diskussioner om sexualitet som sådan. I praktiken finns det andra normer som styr olika handlingar. De senare normerna är könsspecifika (Jeffner 1997). Trots att det eftersträvansvärda anger att båda könen i huvudsak bör utöva sin sexualitet i en romantisk relation är det mer acceptabelt för pojkar än för flickor att ha sex även utanför en kärleksrelation (se ex. Edgardh 1992, Jeffner 1997). Trots att flickor idag i större utsträckning skiljer mellan sex och kärlek förväntas de inte 
agera därefter. De ska varken vara alltför ivriga till sexuellt initiativtagande eller alltför otillgängliga för killars önskemål. De ska företräda en av andra definierad »lagom sexualitet" som bäst realiseras genom en ömsesidig heterosexuell kärleksrelation (Berg 1999, Bäckman 2003). Normer och ideal om tjejers sexualitet är dessutom nära sammankopplande med klassdimensioner. Flickor från bättre ekonomiska förutsättningar väljer i större utsträckning att agera i likhet med den normativa kvinnligheten än vad som är fallet för flickor från sämre ekonomiska förhållanden. Det är vanligare bland de sistnämnda flickorna att identifiera sig med det som betraktas vara "okvinnligt" (Ambjörnsson 2004, Berggren 2001). Det finns indikationer på att föreställningar om könsspecifika normer kring sexualitet är under förändring och att det sker en upplösning av den starka kopplingen mellan kärlek och sexualitet. Dock finns det stora skillnader mellan ungdomar av olika härkomst och framförallt tjejer är restriktivare i sin inställning till frågor som utmanar »kärleksmoralen«(Forsberg 2005).

\section{Skillnader utifrain Etnicitet}

Det är först på 1990-talet som svenska studier om ungdomssexualitet uppmärksammar ungdomar med annan etnisk bakgrund än svensk. Forskningen fokuserar dock uteslutande på mötet mellan det som anses vara "svenskt» och det som definieras som "utländskt» och beskriver de kulturkonflikter som kan uppstå i skärningspunkten mellan olika gruppers föreställningar om framförallt kvinnans sexualitet och för- väntade roll. Skillnader i föreställningar om sexualitet är förhållandevis små mellan ungdomar med svensk bakgrund och ungdomar med utländsk bakgrund som varit bosatta i Sverige under längre tid (Lewin 1991). De skillnader som framträder, när hänsyn tas till ungdomarnas bakgrund är tydligast mellan flickor. Pojkar delar i stor utsträckning samma åsikter. De skillnader bland pojkar som har uppmärksammats visar att pojkar med utländsk bakgrund brottas med den kontrasterande bilden av kvinnan som sexuellt objektiverad och kvinnan som oskuldsfull flicka, där pojkarna i den senare ser en tänkbar framtida partner. Flickorna ger istället uttryck för en nyfunnen frihet och försöker göra upp med de föreställningar om kvinnans roll som finns i deras hemländer (Henriksson \& Lundahl 1993).

Studier från början av 2000-talet innehåller beskrivningar av "nyau sexualmönster som främst påträffas i områden med hög representation av ungdomar med utländsk bakgrund. Studierna tar avstamp i hur synen på samlevnad och sexualitet bland ungdomar formas i mötet mellan olika normer och värderingar. Ungdomarna är påverkade av majoritetssamhällets syn på samlevnad och sexualitet på samma gång som de är lojala mot de värderingar som förmedlas till dem av deras föräldrar. I skärningspunkten mellan olika värderingar växer komplexa relationsmönster fram. De tar sig nya uttryck i osäkerhet som leder till att ungdomar hamnar i konfliktpositioner. Värderingskonflikter uppstår mellan majoritetssamhällets mer sexualliberala synsätt och en uppluckring av traditionella sexuella könsidentiteter där killars och tjejers värde- 
ringar närmar sig varandra (se ex. Forsberg 2005, Hammarén 2003, Lööf \& Folkhälsoinstitutet 1999).

Det finns även normerande föreställningar som begränsar killars sexuella handlingsutrymme. Sexuellt utlevande killar kan betraktas som opålitliga. Vissa killar tolkar det som något positivt men det finns även dem som ser det som en belastning och menar att ett dåligt rykte bland landsmän försvårar valet av en framtida partner. Många pojkar, även de med svensk bakgrund, ger uttryck för en ambivalent inställning i föreställningar om sexualitet. De växlar mellan ett restriktivt sexualideal och en mer öppen syn på sexualitet (Hammarén 2003).

\section{Oskuldens särskilda betydelse}

I Folkhälsoinstitutets forskningsrapport avseende ungdomar och sexualitet konstateras det att oskuldstemat i obetydlig grad har undersökts inom tidigare svensk sexualitetsforskning (Forsberg 2006). De gånger temat berörts i forskningen beskrivs det som något som inte finns i Sverige och inte riktigt berör "oss" utan är en företeelse som finns i andra länder (Forsberg 2000, 2006). Under senare år har emellertid studier om oskuldens särskilda betydelse bland flickor med utländsk bakgrund belysts av ungdomsforskare. Gemensamt för dessa studier är att de analyserar relationen mellan begreppen rykte, oskuld och heder.

Förståelsen av oskuld som avgränsad till kvinnlig kyskhet, det vill säga frånvaro av föräktenskapliga sexuella relationer och på vilket sätt det påverkar flickors handlingsmöjligheter har uppmärksammats (Andersson 2003, Eldén 2003, Forsberg 2005, Wikan 2005). Ryktet om den förlorade oskulden oavsett sanningshalten i detta rykte är vad Eldén (2003) menar är den kulturella kärnan för vad som är vanhedrande.

Krav på avhållsamhet från föräktenskaplig sex innebär i dess mest konkreta innebörd att vara oskuld med mödomen intakt när äktenskap ingås. Förväntningarna och kraven på oskuld är mer explicit uttryckta för flickor med utländsk bakgrund. Kravet på oskuld kontrollerar även andra områden och situationer i flickornas liv än enbart sexualiteten (Andersson 2003, Berg 1994). Flickor hindras från att delta i vissa idrottsaktiviteter eftersom deras familjer tror att det kan skada deras mödom (Salam 2005). En mödomshinna som inte är intakt är enligt vissa traditionella övertygelser symbolen för förlorad heder oberoende av om det förorsakats av ett samlag eller ej (Salam 2005). Även flickornas umgänge och handlingsutrymmen inskränks och det finns exempel på flickor som "lovas bort « $i$ arrangerade äktenskap och tvångsäktenskap (jmf Akpinar 2003, Jemteborn 2005, Schlytter 2004). Oskuldskravets utvidgning är också problematiskt då kollektivets brist på förtroende och ständiga misstänksamhet som riktas mot de unga flickorna, i sig själv kan ge intryck av överdriven sexualisering. Det leder till att unga flickor tvingas att vara vaksamma över alla tänkbara situationer som kan tolkas i sexuella termer (Andersson 2003).

Ungdomars samlagsdebut ger en bild av de föreställningar som styr flickors 
respektive pojkars sexuella möjligheter i samhället. I Sverige är åldern för samlagsdebuten lägre för flickor än för pojkar bland ungdomar med svensk bakgrund (se ex. Edgardh 1992, Lewin \& Fugl-Meyer 1998). För ungdomar med utländsk bakgrund råder det omvända förhållandet. Studier där hänsyn tagits till ungdomars härkomst visar att pojkar med utländsk bakgrund, i större utsträckning än flickor med utländsk bakgrund, gör sin samlagsdebut under högstadietiden (Edgardh 2001, Forsberg 2005). Resultatet kan ha sin förklaringsgrund i den mer restriktiva syn på flickors sexualitet (jmf Edgardh 2001) som finns främst bland vissa etniska minoritetsgrupper.

Liknande resultat framgår även av internationella studier. Ungdomar i USA med bakgrund i Asien visar en mer intolerant inställning till föräktenskaplig sex och uppger en högre »önskvärd" genomsnittålder för samlagsdebut (Okazaki 2002). Gymnasieungdomar i Kina och framförallt flickor accepterar i mindre utsträckning sex innan äktenskap i jämförelse med ungdomar i England (Higgins et al. 2002). Unga kvinnor med grekisk härkomst har långt mer begränsat sexuellt handlingsutrymme än unga kvinnor bland majoritetsbefolkningen i Australien (Callan \& Gallios 1985). Internationella studier pekar även på att oskuldsnormer har samband med ungdomars sexuella hälsa (Keys et al. 2006). Normerna kring oskuld kan i viss utsträckning bidra till en genomsnittlig sänkning av oönskade tonårsgraviditeter, de kan också leda till en lägre medvetenhet om sexuella risker och till en sänkning av preventivmedelsanvändning bland tonår- ingar som gör motstånd mot normerna. Det senare kan leda till en försämrad reproduktiv hälsa, exempelvis på grund av tidiga graviditeter (Keys et al. 2006). Studier som kan relateras till ungdomars syn på sexualitet och sexuella erfarenheter har hitintills varit mer inriktade på att undersöka på vilket sätt oskuldskravet påverkar framförallt flickor med utländsk bakgrund. Det finns lite forskning kring huruvida oskuldskravet påverkar pojkar och i så fall på vilket sätt. Inom svensk sexualitetsforskning finns likaså inga studier som kvantitativt studerat ungdomars föreställningar kring oskuldstemat.

\section{Metod}

Denna studie består av en enkätundersökning som genomfördes under höstterminen 2002 i en större kommun. Det externa bortfallet är nio proccent. Den primära ambitionen i urvalet av undersökningspopulationen var att få en så bred socioekonomiskt spridning som möjligt samt att urvalet skulle ge goda möjligheter att jämföra föreställningar bland ungdomar med svensk bakgrund och ungdomar med utländsk bakgrund. Geografiskt är de utvalda skolorna belägna utanför stadskärnan i stadsdelar med god spridning av olika boendeformer. I skolorna finns följaktligen elever från olika bostadsområden och med skilda socioekonomiska förhållanden samt en högre andel elever med utländsk bakgrund än riksgenomsnittet. Studiens generaliserbarhet begränsas till områden liknande det som beskrivs ovan. Snarlika områden förekommer framförallt i städer och vissa stor- 
stadsförorter. Det är mer tveksamt om man kan generalisera till områden där majoriteten av invånarna har svensk bakgrund. Det interna bortfallet är begränsat och är för de flesta variabler mellan 1-5 procent. ${ }^{4}$

De föreliggande analyserna utgår från påståenden som fokuserar på oskuldens särskilda betydelse för flickor respektive för pojkar. Formuläret har till viss del utformats från frågor som använts i tidigare studier, men enkäten innefattar också påståenden som konstruerats för att mer specifikt undersöka tankemönstret bland elever som går i högstadieskolor med högre andel elever med utländsk bakgrund.

Statistikprogrammet SPSS har använts för sammanställningen och bearbetningen av enkätmaterialet. För att få en övergripande bild av materialet redovisas frekvens- och korstabeller. Sambanden har testats med $x^{2}$-test och Fischers exakta test i de fall då den oberoende variabeln är dikotom. Endast signifikanta resultat redovisas i den löpande texten. För en fördjupad förståelse av studiens frågeställning har multivariata logistiska regressioner utförts. I föreliggande studie används multivariata regressioner för att ta reda på den oberoende variabelns, exempelvis etnicitets, inverkan på den beroende variabeln samtidigt som övriga oberoende variabler i modellen konstanthålls (för för-

4 Föräldrars yrke och utbildning omfattas av ett högre bortfall. Möjlig förklaring till detta är att en utländsk utbildning kan vara svår att omvandla till en svensk motsvarighet för vissa ungdomar. Ungdomar kan ha varit osäkra på föräldrarnas yrke och därför valt att inte svara på frågan. (Utbildning, 12\%. Yrke, 8\%). djupad diskussion se Lagerberg \& Sundelin 2000). Logistiska regressioner är lämpliga att använda när den beroende variabeln är dikotom. I denna studie har de beroende variablernas fyra svarsalternativ slagits samman till två närmare bestämt instämmer, respektive instämmer inte, i regressionsanalyserna. ${ }^{5}$ Det är således inte graden av viss inställning som studeras utan huruvida ungdomen ansluter sig till ett visst påstående eller inte. Resultaten redovisas i form av oddskvoter, vilka visar den direkta inverkan av en faktor efter kontroll för annan inverkan. Oddskvoterna anger hur troligt det är att en given grupp intar en viss given attityd i relation till dess förekomst i referenskategorin. ${ }^{6}$ Oddskvoter över 1 innebär att attityden är mer vanligt förekommande. Oddskvoter under 1, att de är mindre vanligt förekommande.

\section{Socialbakgrund}

Ungdomarnas etniska bakgrund fokuserar på hur länge familjen bott i Sverige. Ungdomar födda utomlands utgör den grupp som bott kortast tid i Sverige, dock högst i 15 år. Ungdomar som är födda i Sverige har delats in i tre grupper; ungdomar med två svenskfödda föräldrar även kallade ungdo-

5 De fyra svarsalternativen är »nej instämmer absolut inte", "instämmer inte», »instämmer nästan" och »ja instämmer absolut». Analyser har även företagits med denna indelning. Signifikansnivåerna var i stort sett lika oavsett vilken indelning som användes.

6 Oddset för referenskategorin är satt till 1 och är i tabellerna markerat med »1". 
mar med svensk bakgrund, ungdomar med en utlandsfödd förälder och ungdomar med två utlandsfödda föräldrar. ${ }^{7}$ Majoriteten av de ungdomar som har två utlandsfödda föräldrar eller de ungdomar som själva är födda utomlands har sin bakgrund utanför Europa. I texten presenteras resultat från gruppen ungdomar med svensk bakgrund, ungdomar med två utlandsfödda föräldrar och ungdomar som själva är födda utomlands. När resultatet refererar till ungdomar med två utlandsfödda föräldrar oberoende av om den unge själv är född i Sverige eller inte används uttrycket ungdomar med utländsk bakgrund. Ungdomar med en utlandsfödd förälder utgör en mycket heterogen grupp med svårtolkade resultat till följd. De har därför uteslutits från de flesta analyser.

I tidigare studier lyfts ytterligare bakgrundsfaktorer fram som viktiga då de påverkar ungdomars erfarenheter och föreställningar om sexualitet. En sådan faktor är socioekonomiska förhållanden och reli-

7 Ungdomar med svensk bakgrund har båda sina föräldrar födda i Sverige men de kan ha far- och morföräldrar födda i ett annat land. Även adopterade som själva är födda utomlands finns representerade i gruppen. Ungdomarna i gruppen en utländsk förälder är själva födda i Sverige med en förälder född i Sverige och en förälder född i ett europeiskt land. Förhållandevis få har en förälder född i ett land utanför Europa. I gruppen finns undantagsvis ett mycket begränsat antal familjer (nio familjer) där den unge själv tillsammans med en av föräldrarna är född utomlands. Per definition hör dessa ungdomar till gruppen "födda utomlands». Valet att inkludera dessa ungdomar i gruppen »en förälder född utomlands" baseras på att den unge i de flesta fall bor med den svenskfödda föräldern. giositet. I denna studie kontrolleras inverkan av socioekonomiska förhållanden med variablerna föräldrars yrke och föräldrars utbildning. Föräldrarnas yrke har indelats enligt Statistiska Centralbyråns socioekonomiska klassificering (SCB 1982). ${ }^{8}$ Familjerna har delats in efter den förälder vars yrke tillhör den högsta kategorin. Ibland är yrkesnivån fastställd utifrån fadern, men i nästan lika stor utsträckning utifrån modern. Likaså är föräldrars utbildning. ${ }^{9}$ Variabeln föräldrars religiositet är en sammanslagning av tre frågor. Ungdomarna har fått ta ställning till hur ofta familjen besöker religiösa församlingslokaler samt hur religiös modern respektive fadern uppfattas av den unge själv. Kontroll görs även för ungdomarnas ålder med utgångspunkt ifrån variabeln årskurs. Variabeln kategoriseras enligt den årskurs eleven vid enkätgenomförandet gick i. ${ }^{10}$

\section{Föreställningar om oskuld}

I analyserna används fyra frågor för att ta

8 Föräldrar som arbetar som tjänstemän på mellan och låg nivå har slagits ihop eftersom antalet tjänstemän på låg nivå är begränsat. Sammanslagningen påverkar inte resultaten i analyserna.

9 Variabeln är indelad i tre kategorier; högskoleeller universitetsutbildning, högst gymnasieutbildning och högst grundskola.

10 Enkätstudien har genomförts i en högstadieskola med årskursindelning sju, åtta och nio. Det kan i undersökningsgruppen ha förekommit att enstaka elever gick i en årskurs och var äldre/yngre än majoriteten av eleverna som gick i samma årskurs vid enkätgenomförandet. 
reda på hur vanligt förekommande det är att ungdomar instämmer i normer som begränsar föräktenskapliga sexuella relationer. Valet av utfallsvariabler stöds av utfallet i en faktoranalys av enkätens frågeställningar (redovisas ej). Vid en första genomgång har flera frågor analyserats som kan tänkas vara intressanta för studiens syfte varvid antalet faktorer har fastställts och variabler med låg laddning har sorterats bort. Ungdomarnas föreställningar som speglar en positiv inställning till respektabilitetsnormer kan tolkas på olika sätt. Dels kan de stå för en traditionell syn på föräktenskapliga sexuella relationer utifrån ett "självvalt« ställningstagande, dels kan de vara grundade i en mer restriktiv syn på sexualitet som också inkluderar och tar hänsyn till omgivningens uppfattning om föräktenskapliga sexuella relationer. Påståendena »tjejer ska vara oskuld när de gifter sig" och "killar ska vara oskuld när de gifter sig" är i första hand mått på det »självvalda» ställningsta- gandet. Påståendena "föräldrar ska kunna bestämma att deras döttrar ska vänta med sex tills de gifter sig" och "föräldrar ska kunna bestämma att deras söner ska vänta med sex tills de gifter sig" avser mäta föreställningar om den syn på sexualitet som också inkluderar och tar hänsyn till omgivningens uppfattning och krav på oskuld.

Frågorna som ställts till respondenterna är inspirerade av forskningsresultat från studier om ungdomar och sexualitet (se ex. Forsberg 2000, Daugherty \& Burger 1984). Det är viktigt att uppmärksamma att frågorna kan tolkas olika av respondenterna. Exempelvis kan eleverna ha svarat på enkätens frågor utifrån olika utgångspunkter. Detta kan framkalla både under och överrapportering av tillåtande eller avståndstagande attityder. Påståendena kan också upplevas som känsliga och/eller utmanande av vissa elever och det kan i sin tur föranleda socialt önskvärda svar respektive protestsvar.

\section{Resultat}

\section{Undersökningsgruppens sammansättning}

Tabell 1 visar att undersökningsgruppens könsfördelning är jämn med något fler flickor. Inom gruppen elever med utländsk bakgrund är 13 procent födda i Sverige med utlandsfödda föräldrar och 17 procent är själva födda utomlands. Av samtliga elever har 22 procent rötter i Mellanöstern. Mer än hälften av eleverna uppger att deras föräldrar arbetar inom tjänstemannayrken. Majoriteten av eleverna har högutbildade föräldrar och ungefär en tiondel har föräldrar med högst grundskoleutbildning. En relativ liten andel ( $8 \%$ ) av eleverna uppger att deras 
föräldrar är mycket religiösa och 35 procent anger att deras föräldrar är ganska religiösa.

\section{Ska man vara gift först?}

Ungefär en femtedel av alla högstadieelever »instämmer absolut" eller sinstämmer nästan"i att en tjej respektive en kille ska vara oskuld vid ingåendet av äktenskap. En intressant iakttagelse är att det inte är någon större skillnad i ungdomarnas svar beroende på om frågan avser en flicka eller en pojke. Däremot är det fler ungdomar som »absolut inte instämmer" ( $47 \%)$ i att en kille ska vara oskuld i jämförelse med de 39 procent som svarar detsamma när frågan avser en tjej. I det följande redovisas resultat från analyser, där förutom kön, hänsyn även tagits till respondenternas etniska bakgrund.

\section{Tabell 1.}

Undersökningsgrupper antal och andel (\%). N=1193.

\begin{tabular}{|c|c|c|}
\hline & Antal & Andel $\%$ \\
\hline \multicolumn{3}{|l|}{ Kön (n=1191) } \\
\hline Pojkar & 583 & 49 \\
\hline Flickor & 608 & 51 \\
\hline \multicolumn{3}{|l|}{ Årskurs(n=1187) } \\
\hline Sjuan & 449 & 38 \\
\hline Åttan & 389 & 33 \\
\hline $\mathrm{N}$ ian & 349 & 29 \\
\hline \multicolumn{3}{|l|}{ Etnisk bakgrund (n=1193) } \\
\hline Svensk bakgrund & 677 & 57 \\
\hline En utlandsfö dd förälder & 163 & 14 \\
\hline Båda fö räldrarna utlandsfödda & 152 & 13 \\
\hline D en unge själv utlandsfö dd & 201 & 17 \\
\hline \multicolumn{3}{|l|}{ Föräldrarsyrke (n=1110) } \\
\hline Tjänstemän, mellan och låg & 412 & 37 \\
\hline Tjänstemän,hög & 191 & 26 \\
\hline Arbetare,facklärda & 159 & 14 \\
\hline Arbetare,ej facklärda & 156 & 14 \\
\hline Ingen förälder arbetar & 92 & 8 \\
\hline \multicolumn{3}{|c|}{ Föräldrars utbildningsnivå ( $n=1046)$} \\
\hline Högst grundskola & 112 & 11 \\
\hline Högst gymnasium & 186 & 18 \\
\hline Högskola/universitet & 748 & 71 \\
\hline \multicolumn{3}{|c|}{ Föräldrars religiositet $(n=1192)$} \\
\hline Inte särskilt religiösa & 678 & 57 \\
\hline Ganska religiösa & 421 & 35 \\
\hline Mycket religiösa & 93 & 8 \\
\hline
\end{tabular}




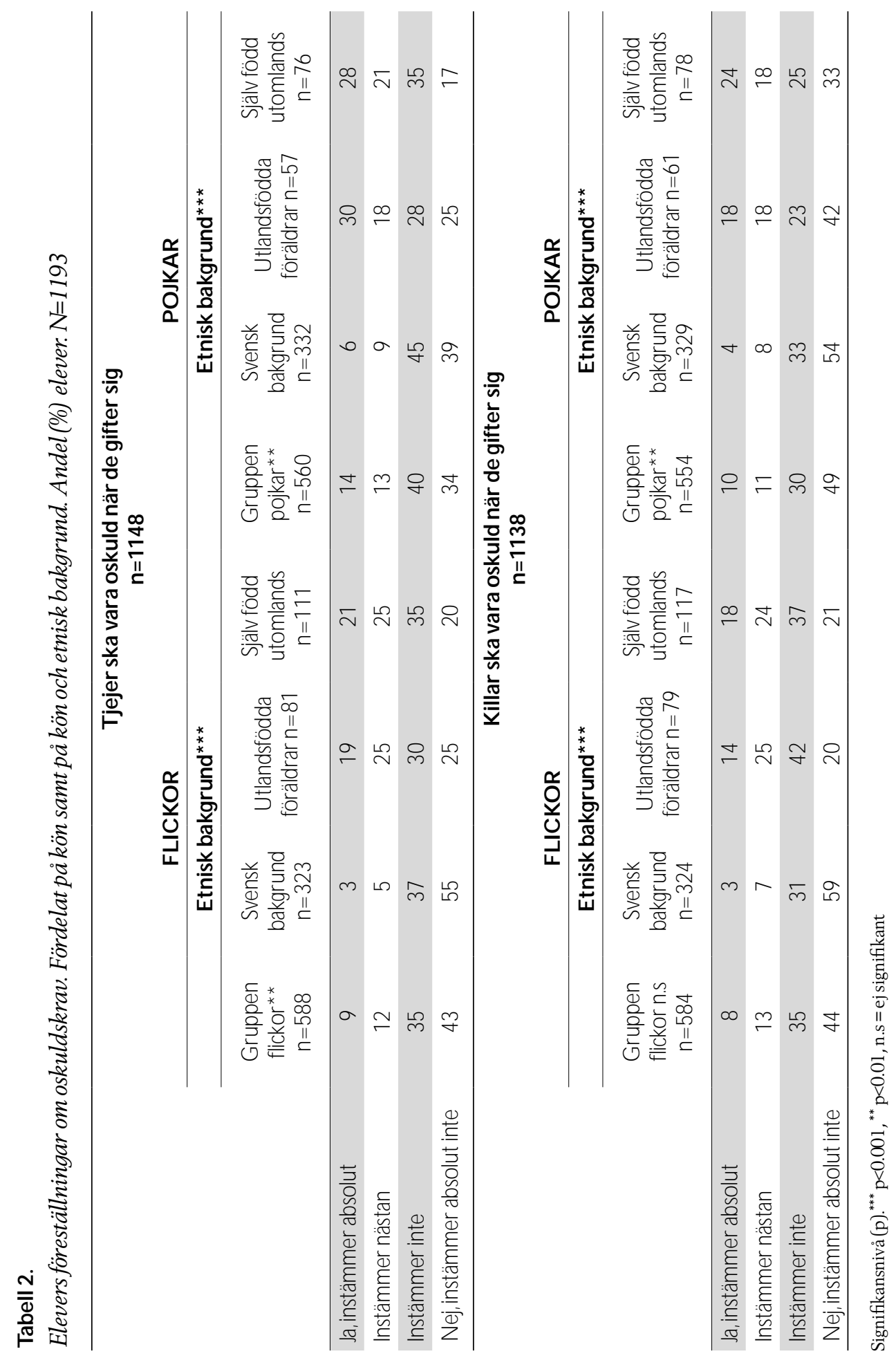

Socialvetenskaplig tidskrift nr $1 \bullet 2007$ 
När hänsyn tas till respondenternas kön framträder ett resultat som visar att fler pojkar än flickor är positiva till att »tjejer ska vara oskuld innan de gifter sigu. Motsvarande könsskillnad finns inte i påståendet »killar ska vara oskuld». Ett mer sammansatt mönster framträder när analysaxlarna rör sig mellan två perspektiv. Den bild som framträder visar både skillnader och likheter mellan olika grupper när det gäller såväl etnisk bakgrund som kön. Ett gemensamt mönster visar att majoriteten av eleverna tar avstånd ifrån normer som begränsar ungdomars föräktenskapliga sexuella handlingsutrymme. När detta resultat kontrolleras för elevernas etniska bakgrund framträder en mer nyanserad bild som visar att andelen som tar avstånd från normer som inskränker på det sexuella handlingsutrymmet är högre bland ungdomar med svensk bakgrund i jämförelse med ungdomar med utländsk bakgrund.

I påståendet "tjejer ska vara oskuld" svarar en mycket begränsad andel (3\%) av flickorna med svensk bakgrund att de "absolut instämmer" i att en tjej respektive en kille ska vara oskuld när äktenskap ingås. Flickor födda utomlands är de som i störst utsträckning "instämmer absolut» (21\%) i att en tjej respektive en kille (18\%) ska vara oskuld när äktenskap ingås. Resultatet för flickor med utlandsfödda föräldrar är 19 procent när frågan avser en tjej och 14 procent när den avser en kille.

En liten andel (6\%) av pojkarna med svensk bakgrund "instämmer absolut" i att en tjej ska vara oskuld och fyra procent instämmer i att en kille ska vara det. Motsvarande resultat för pojkar födda utomlands är 28 procent när frågan avser en tjej och 24 procent när den avser en kille. Pojkar med utlandsfödda föräldrar anser att en kille ska vara oskuld (18\%) i mindre utsträckning än en tjej (30 \%). När fokus skiftas till könsskillnaderna inom respektive svarsgrupp framträder nya resultat. ${ }^{11}$ Inom gruppen ungdomar med svensk bakgrund instämmer flickor i mindre utsträckning än pojkar i påståendet att "tjejer ska vara oskuld". Könsskillnaderna inom övriga grupper redovisas ej eftersom de inte är tillräckligt stora för ett statistiskt signifikant resultat.

\section{Ska andra bestämma?}

Tidigare forskning har visat att föreställningar om respektabilitet bottnar i en striktare sexualmoral som i synnerhet innebär en övervakning av flickors handlingsutrymme för att säkerställa deras oskuld (se ex. Forsberg 2006). Med utgångspunkt i detta är det rimligt att ta reda på hur ungdomarna ställer sig till att deras sexuella handlingsutrymme begränsas av deras föräldrar. Ungdomarna har fått ta ställning till två påståenden som ämnar fånga upp deras syn på föräldrars inflytande i en dotters respektive en sons föräktenskapliga sexuella möjligheter.

Omkring hälften av de tillfrågade eleverna är mycket kritiska (»instämmer absolut inte"i) och ungefär en tredjedel är negativa ( "instämmer inte") till föräldrars inflytande

$11 \mathrm{Med}$ svarsgrupp avses uppdelning utifrån etnisk bakgrund. Det vill säga ungdomar med svensk bakgrund bildar en svarsgrupp, ungdomar med utlandsfödda föräldrar bildar ytterligare en svarsgrupp och så vidare. 


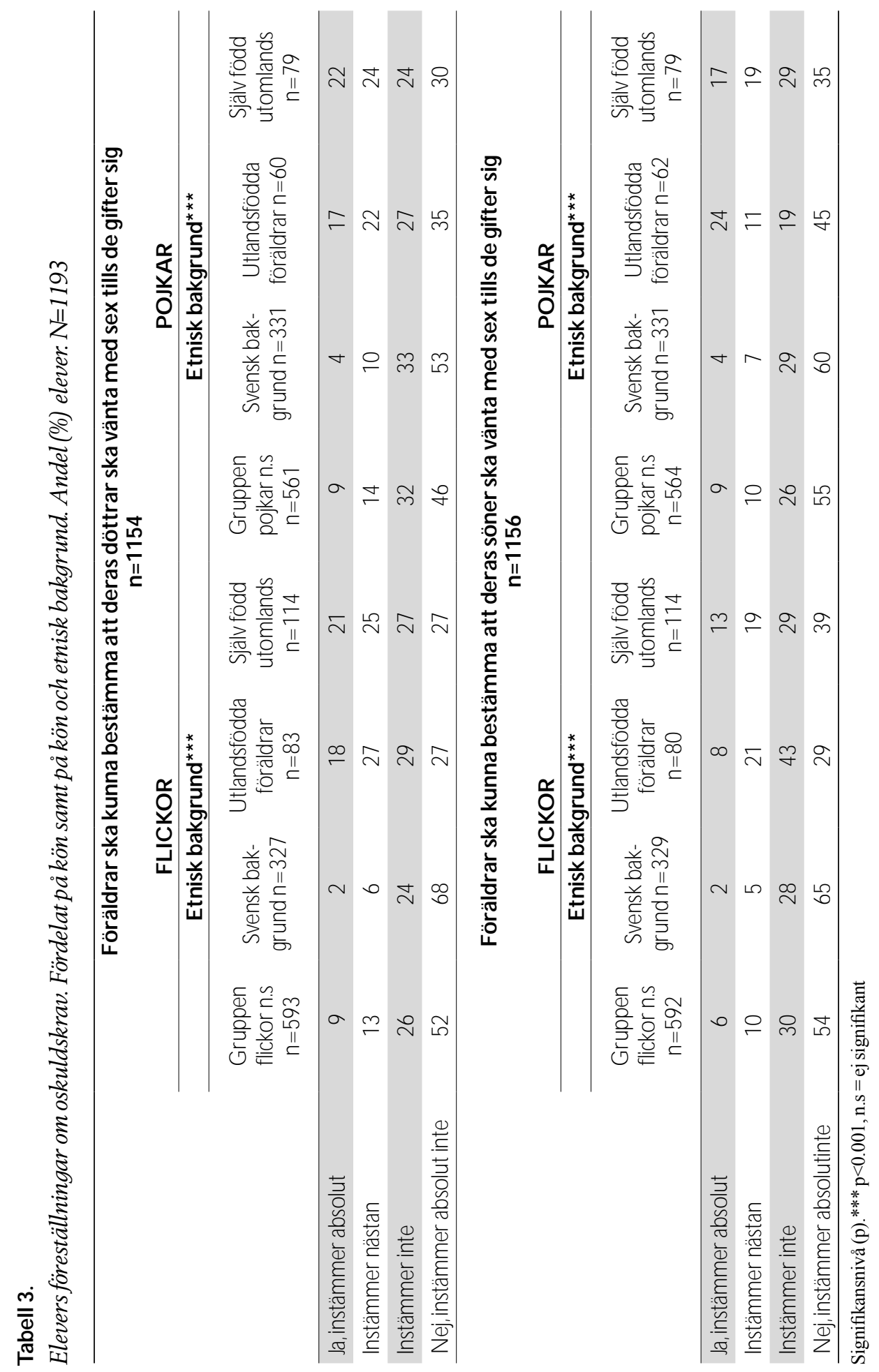

Socialvetenskaplig tidskrift nr 1 • 2007 
över en dotters respektive en sons sexuella handlingsutrymme. Ungefär var femte elev svarar "ja instämmer absolut" eller »instämmer nästan« i föräldrars inflytande över ungdomars sexualitet. Skillnaderna är inte stora beroende på om frågan avser en tjej eller kille.

När fokus riktas mot elevernas etniska bakgrund kvarstår de tidigare redovisade skillnaderna mellan ungdomar med olika bakgrund. Bland flickor uppger endast två procent av dem med svensk bakgrund att de absolut instämmer i att "föräldrar ska kunna bestämma att en dotter eller en son ska vänta med sex tills de gifter sigu. Bland flickor som själva är födda utomlands instämmer 21 procent i påståendet när det gäller en dotter och färre instämmer i detsamma när det gäller en son (13 $\%)$. Bland flickor som har utlandsfödda föräldrar instämmer 18 procent i föräldrars inflytande i en dotters sexuella handlingsutrymme och lägre andel (8\%) instämmer i detsamma för en son. Det är framförallt sistnämnda flickor som uttrycker en annan syn på föräldrars inflytande när det avser en dotters sexuella handlingsutrymme än vad de gör för en sons.

Bland pojkarna är det pojkar med svensk bakgrund som är mest negativa till föräldrars inflytande över en dotters (4\%) respektive en sons (4\%) sexuella handlingsutrymme. Det är vanligare att pojkar födda utomlands anger att föräldrar ska kunna bestämma över en dotters (22 \%) och/eller en sons (17\%) sexuella handlingsutrymme. Resultatet bland pojkar med utlandsfödda föräldrar är 22 procent avseende det förstnämnda och 17 procent för det senare.

\section{Det somförenar och det som skiljer åt}

I Tabell fyra skiftas fokus till att ta reda på huruvida ungdomar som instämmer i normer som begränsar exempelvis en flickas sexuella handlingsutrymme även instämmer i normer som begränsningar en pojkes sexuella handlingsutrymme. För att få en överskådlig bild av nyss nämnda mönster presenteras resultat som åskådliggör andelen ungdomar som endast instäm mer $i$ att en tjej ska vara oskuld men inte en kille och tvärtom. På motsvarande sätt presenteras resultatet för de påståenden som avser föräldrars inflytande i oskuldsfrågan. I nedre delen av Tabell 4 redovisas andelen ungdomar som anger att en tjej eller en kille ska vara oskuld men som också anger att föräldrar ska kunna bestämma i detsamma samt andelen ungdomar som inte instämmer i något av de fyra påståendena. Föreställningarna bland de sistnämnda kan betraktas som en kombination av ett personligt val, på samma gång som svaren rymmer ett erkännande av krav och/eller förväntningar från familj/släkt. Ungdomars föreställningar som refererar till båda förhållningssätten kan även tolkas som ett uttryck för en så kallad »oskuldskontext«.

\section{Endast tjejer ska vara oskuld}

Resultatet i övre delen av Tabell 4 visar att flickor i större utsträckning står bakom uppfattningen att tjejer och killar ska värderas efter ungefär samma måttstock. Exempelvis är det en begränsad andel flickor som instämmer i att det ena könet ska vara 


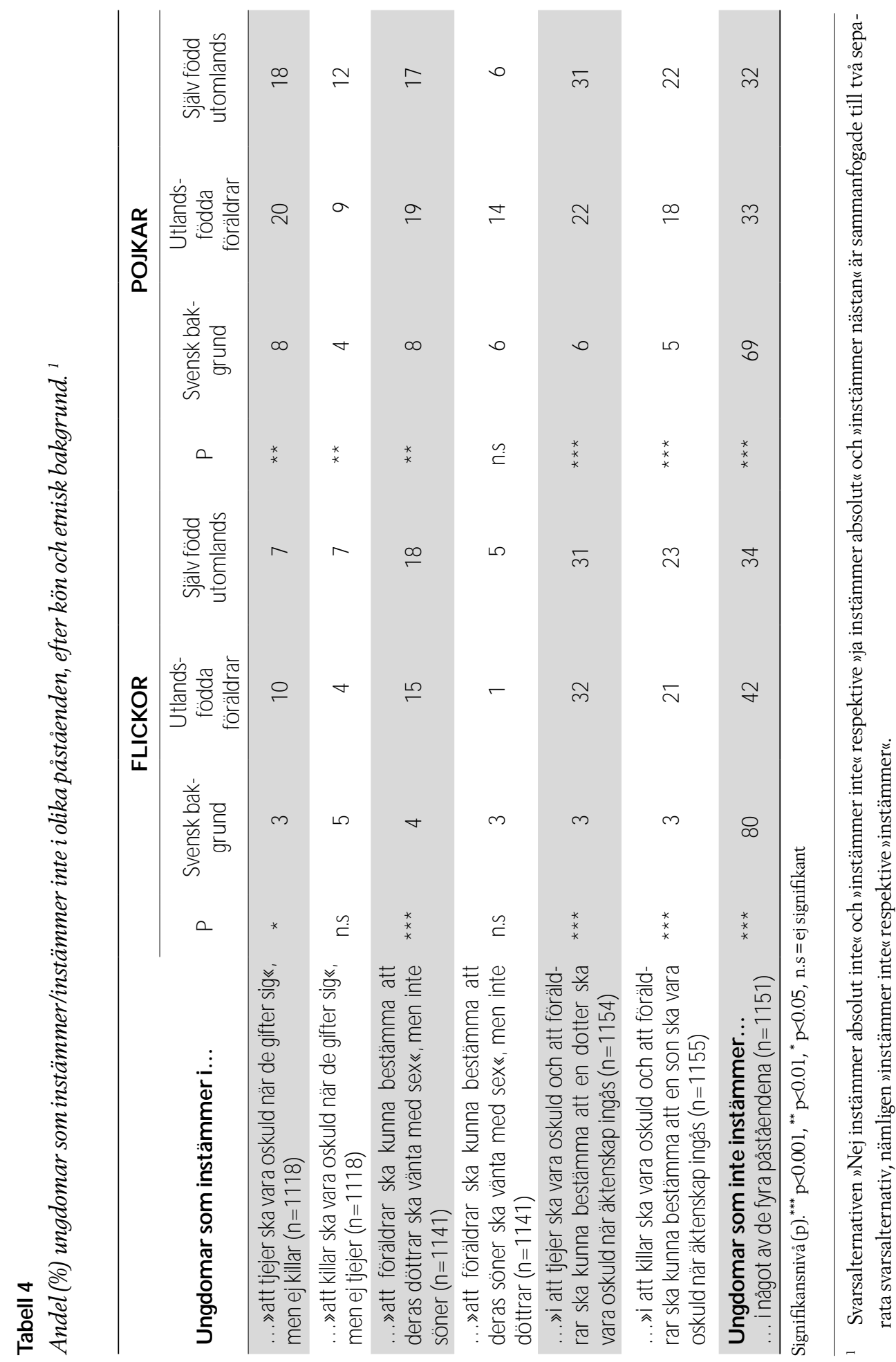

Socialvetenskaplig tidskrift nr 1 • 2007 
oskuld men inte det andra. Flickor bedömer frågorna "tjejer ska vara oskuld men inte killar" och omvänt "killar ska vara oskuld men inte tjejer" ungefär lika. ${ }^{12}$ Resultat kan tolkas som uttryck för protestsvar som ämnar ta avstånd från rådande könsrollsförväntningar. Om en tjej ska vara oskuld så ska även en kille vara det. ${ }^{13}$ Till skillnad från flickorna visar svaren bland pojkarna att en högre andel instämmer $i$ att endast tjejer ska vara oskuld än omvänt. Resultatet är tydligast bland pojkar med utlandsfödda föräldrar. Bland ungdomar med utländsk bakgrund är det sammanfattningsvis en högre andel som uttrycker att båda könen ska vara oskuld när äktenskap ingås.

\section{Föräldrar ska få mer inflytande övertjejers sexuella handlingsutrymme}

Tidigare forskning har visat att kravet på oskuld för med sig en rad begränsningar som framförallt gäller flickors sexuella handlingsutrymme (se ex. Akpinar 1998, Eldén 2003, Mørck 2000, Wikan 2005). Det är därför intressant att närmare studera huruvida ungdomars föreställningar kring föräldrars rätt att bestämma över det

12 Resultatet anger jämförelser inom respektive svarsgrupp. Det vill säga exempelvis flickor med svensk bakgrund bedömer frågan om oskuld ungefär lika för båda könen. Resultatet anger inte i vilken utsträckning nyss nämnda grupp instämmer i frågorna.

13 Flickor med utlandsfödda föräldrar utgör ett undantag. En högre andel instämmer i att endast tjejer ska vara oskuld. sexuella handlingsutrymmet också följer ett könsspecifikt mönster. Synsättet »att bedöma könen efter ungefär samma måttstock" som åskådliggjorts ovan kvarstår endast bland flickor med svensk bakgrund. Bland flickor med utländsk bakgrund framträder ett nytt mönster som visar en mer accepterande syn avseende föräldrars inflytande $i$ en dotters sexuella handlingsutrymme. Resultatet kan även tolkas som att flickor är mer samstämmiga i sina förställningar så länge frågan avser föräldrars inflytande i söners sexuella utrymme men att deras åsikter går isär när frågan avser döttrars sexuella handlingsutrymme. En rimlig förklaring skulle kunna vara att flickor med utländsk bakgrund svarar på enkätens frågor med utgångspunkt i en upplevd vardagsverklighet. De definierar sig själva utifrån en betydligt striktare föreställning och krav för hur en ung kvinna ska agera för att inte skada familjens och sitt eget anseende.

Resultatet bland pojkarna följer ungefär samma mönster som för flickorna. Pojkar är generellt mer samstämmiga i sina svar när frågan avser föräldrars inflytande i söners sexuella handlingsutrymme. Emellertid framträder det ett nytt mönster bland pojkar med utländsk bakgrund som inte har sin motsvarighet bland flickor med utländsk bakgrund. Det är framförallt pojkar födda utomlands som ger uttryck för en mer accepterande inställning till föräldrars inflytande i en dotters sexuella handlingsutrymme. Pojkar med utlandsfödda föräldrar ger uttryck åt en mer likvärdig bedömning av föräldrars inflytande i båda könens sexuella handlingsutrymme. Resultatet kan uppfattas på olika sätt. En tolkning kan vara att pojkar födda utomlands är mer influe- 
rade av ett synsätt som förespråkar hårdare kontroll av flickors föräktenskapliga sexuella relationer. Pojkar med utlandsfödda föräldrar har gått i svensk skola från årskurs ett och bott i Sverige hela livet. Sannolikt bidrar deras erfarenheter av det svenska samhället till att dessa pojkar anammat en mer öppen inställning till sexualitet.

Bland pojkar med utlandsfödda föräldrar som instämmer i oskuldsnormer finns två mönster. Det första visar att de framförallt uppvisar "liberala" föreställningar beträffande föräktenskaplig sex när det praktiseras av dem själva. ${ }^{14}$ Det andra visar att de inte gör någon skillnad i föräldrars rätt att bestämma över tjejers respektive killars sexuella handlingsutrymme. Även om de förmedlar en mer accepterande syn på föräldrars inflytande i en dotters sexuella handlingsutrymme så förmedlar de en nästan lika accepterande bild beträffande detsamma för en son. Svaren bland nämnda pojkar kan tolkas som att de ger uttryck för en "dubbelmoral" och på samma gång visar svaren den ambivalens som präglar pojkarnas föreställningar om sexualitet (jmf Hammarén 2003).

\section{"Oskuldskontext"}

En återhållsam inställning till föräktenskapliga sexuella relationer kan betraktas som ett mer personligt ställningstagande

14 Se resultat från Tabell 4, där pojkar med utlandsfödda föräldrar i större utsträckning instämmer i att "tjejer ska vara oskuld men inte killar» än omvänt »killar ska vara oskuld men inte tjejer". och/eller som ett erkännande av de krav och/eller förväntningar som individen, av familj/släkt väntas leva upp till. I könssegregerade samhällen är dessa två förhållningssätt hårt knutna till varandra. Resultatet $\mathrm{i}$ denna studie visar att det finns en grupp ungdomar som väljer att svara att en tjej och/eller en kille ska vara oskuld på samma gång som de svarar att föräldrar inte ska kunna få bestämma i detsamma (se Tabell 4). Deras svar kan tolkas som ett mer självvalt ställningsstagande.

Det är mer vanligt förekommande bland ungdomar med utländsk bakgrund att acceptera föreställningar som ger stöd åt en så kallad "oskuldskontext», i synnerhet när det avser en flicka. Exempelvis svarar 32 procent av flickorna med utlandsfödda föräldrar och 31 procent av flickorna och pojkarna födda utomlands att de instämmer i påståendet "tjejer ska vara oskuld" på samma gång som de också instämmer i påståendet att "föräldrar får bestämma att en dotter ska vänta med sex tills hon gifter sig". Färre (omkring $20 \%$ ) svarar desamma när det avser en pojke. Pojkar med utlandsfödda föräldrar utgör ett undantag då de svarar ungefär lika oberoende om påståendet avser en flicka eller en pojke. I västvärlden har sexualiteten mer och mer kommit att handla om individens privata angelägenhet och det är mer ovanligt att föräktenskapliga sexuella relationer kritiseras. Svaren bland ungdomar med svensk bakgrund antyder ett synsätt som tydligt tar avstånd från oskuldsnormer. 80 procent av flickorna och 69 procent av pojkarna med svensk bakgrund instämmer inte i något av påståendena. När resultat jämförs med motsvarande resultat bland ungdomar 
med utländsk bakgrund framträder tydliga skillnader. Endast omkring 30 procent bland sistnämnda ungdomar tar avstånd från oskuldsnormer. Undantaget flickor med utlandsfödda föräldrar där 42 procent inte instämmer i oskuldsnormer. Trots den komplexitet som präglar ungdomarnas svar framträder vissa övergripande mönster. Den tydligaste skiljelinjen går mellan ungdomar med svensk bakgrund och utländsk bakgrund. Andelen ungdomar som ger uttryck för ett avståndstagande från oskuldsnormer är högre bland ungdomar med svensk bakgrund. Ungdomar med svensk bakgrund värderar även i större utsträckning tjejers och killars sexuella handlingsutrymme enligt ungefär samma bedömningsgrund. Det innebär att deras svar i mindre eller ingen utsträckning ger uttryck för "dubbelmoral" med olika föreställningar för en flicka respektive en pojke. Motsvarande tendenser finns i viss utsträckning bland ungdomar med utländsk bakgrund. Redan 1969 skriver Zetterberg att det återhållsamma sexualmönstret saknar stöd hos majoriteten av befolkningen i Sverige. En svag könsskillnad kunde dock urskiljas då fler opponerade sig mot åsikten om föräktenskapliga sexuella relationer när det gällde kvinnor (Zetterberg 1969). I Forsbergs (2005 s.167) studie har frågan "man ska vara gift innan man har samlaguställts till bland annat högstadieelever. Där framkommer det inga könsskillnader bland svaren hos ungdomar med svensk bakgrund. En möjlig förklaring kan vara att frågan är ställd på ett sådant sätt som inte beaktar de könsskillnader som framträder när formuleringen av frågan, som i föreliggande studie, definierar om påståendet avser en tjej eller en kille.

\section{Olika faktorers inverkan på ungdomarnas föreställningar}

Regressionsanalyser har gjorts separat för flickor och pojkar. I de bivariata analyserna presenteras sambandet separat för respektive variabel. Vid analyser av betydelsen av etnisk bakgrund används gruppen ungdomar med svenskt ursprung genomgående som referenskategori. Signifikanta samband förekommer med etnisk bakgrund, föräldrars religiositet, föräldrars yrke och utbildning, samt med ungdomarnas ålder (se Tabell 5). Ett övergripande mönster i resultatet är att oddskvoterna genomgående är högre bland flickor än bland pojkar. Exempelvis är oddset något mer än nio gånger högre för att en utlandsfödd flicka ska instämma i föräldrars inflytande i en dotters sexuella handlingsutrymme än en flicka med svensk bakgrund. Motsvarande oddskvot för en utlandsfödd pojke är något mer än fem gånger högre. Resultatet från de bivariata analyserna visar att skillnaderna i föreställningar mellan flickor med olika etnisk bakgrund är mer framträdande än skillnaderna i föreställningar mellan pojkar med olika etnisk bakgrund. När hänsyn tas till andra sociala bakgrundsfaktorer i de multivariata analyserna närmar sig åsikterna bland flickor med olika etnisk bakgrund varandra framför allt när påståendena refererar till killars och/eller söners sexuella handlingsutrymme. Bland pojkarna kvarstår sambandet med etnisk bakgrund oförändrat.

Bland flickorna uppträder ett mycket starkt samband mellan religiositet och inställning till oskuld. Oddset för att en flicka som kommer från en mycket religiös 


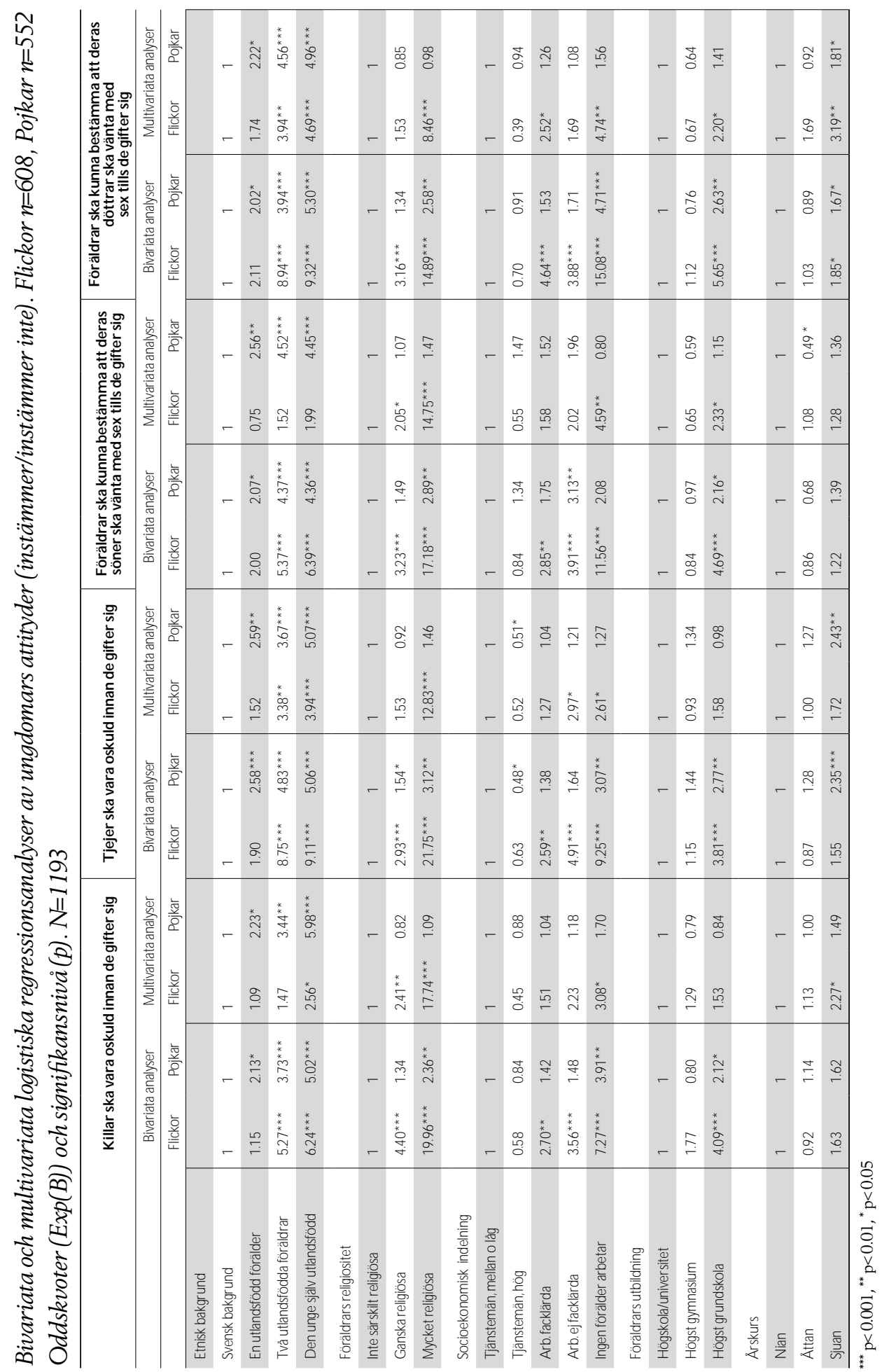

Socialvetenskaplig tidskrift nr $1 \bullet 2007$ 
familj ska instämma i att en pojke ska vara oskuld är nästan 20 gånger högre än för en flicka som uppger att hennes föräldrar inte är särskilt religiösa. Motsvarande resultat för att en flicka ska vara oskuld är närmare 22 gånger högre bland flickor med mycket religiösa föräldrar. Bland pojkarna är oddskvoterna mycket lägre. Exempelvis är oddset tre gånger högre för att en pojke från en mycket religiös familj ska instämma $i$ att en flicka ska vara oskuld än en pojke som uppger att hans föräldrar inte är särskilt religiösa.

Resultatet bland flickorna uppvisar starka samband med föräldrars socioekonomiska bakgrund. Sambandet är starkast bland flickor som uppger att deras föräldrar inte arbetar. Dock förekommer det även samband med föräldrar som tjänstgör inom arbetaryrken. Sannolikheten att en flicka med arbetslösa föräldrar ska instämma i föräldrars inflytande i en sons sexuella handlingsutrymme är mer än elva gånger högre än för en flicka med föräldrar som är tjänstemän på mellan och låg nivå. Motsvarande oddskvot när frågan avser föräldrars inflytande i en dotters sexuella handlingsutrymme är 15 mot 1 . Föräldrars utbildning påverkar också flickornas svar. Flickor som har föräldrar med endast grundskoleexamen är också de som i högre omfattning instämmer i traditionella värderingar.

Även svaren bland pojkarna uppvisar samband med socioekonomisk bakgrund. Emellertid är sambandet endast signifikant bland pojkar som uppger att deras föräldrar inte arbetar. Föräldrars utbildning uppvisar också samband bland pojkarna. Pojkar som uppger att deras föräldrar endast har grundskoleexamen instämmer i större utsträckning i traditionella värderingar. Dock är oddskvoterna lägre bland pojkarna än bland flickorna i jämförelse med respektive referenskategori.

Variabeln årskurs som är ett mått på ungdomarnas ålder uppvisar ett intressant samband bland pojkarna. Ålder förefaller spela roll endast i de påståenden som mäter föreställningar om tjejers sexuella handlingsutrymmen. Oddskvoten för att en pojke som går i årskurs sju ska instämma i exempelvis påståendet "att en tjej ska vara oskuld« är två gånger högre än för en pojke som går $i$ årskurs nio.

När variablerna kontrolleras mot varandra i de multivariata analyserna upphör vissa samband medan andra kvarstår eller tonas ner. Bland pojkarna upphör samtliga samband med föräldrars religiositet, yrke och utbildning. ${ }^{15}$ Däremot kvarstår, mer eller mindre oförändrade samband med etnisk bakgrund och ålder. Resultatet pekar på att pojkar med utländsk bakgrund och/ eller yngre pojkar i större utsträckning ställer sig bakom föreställningar som stödjer en återhållsam inställning till föräktenskapligt sexuellt handlingsutrymme för en tjej respektive en kille.

Bland flickorna tonas sambandet med etnisk bakgrund ner, dock kvarstår sambandet med föräldrars religiositet i stort sätt oförändrad. Sambandet med föräldrars yrke tonas ner och sambandet med föräldrars utbildning kvarstår endast för påståendena avseende föräldrars inflytande i en dotter

15 Pojkar vars föräldrar arbetar som högre tjänstemän instämmer i mindre utsträckning i påståendet. 
respektive sons sexuella utrymme. Därutöver framträder ett samband med ålder. Oddskvoten för att en flicka som går i årskurs sju ska acceptera föräldrars inflytande avseende en dotters sexuella handlingsutrymme är tre gånger högre än bland flickor i årskurs nio. Sammanfattningsvis innebär sambanden att flickor med utländsk bakgrund, och/eller flickor med mycket religiösa föräldrar och/eller med föräldrar inom arbetaryrken och/eller föräldrar som inte arbetar i större utsträckning stödjer traditionella värderingar beträffande ungdomars sexuella handlingsutrymme.

\section{Slutdiskussion}

I föreliggande studie har föreställningar om oskuldsnormer bland högstadieelever undersökts. Den tydligaste skillnaden i materialet är den mellan ungdomar med svensk respektive utländsk bakgrund. Därutöver framkommer samband med kön, klassbakgrund och religiositet. Dock ser sambanden olika ut bland flickor respektive pojkar. När etnisk bakgrund, klassbakgrund samt religiositet kontrolleras mot varandra påverkar de sist nämnda framförallt flickors föreställningar. ${ }^{16}$ Starkt troende föräldrar kan i högre utsträckning vara influerade av traditionella tankemönster i sin uppfostran av en dotter, och kan på så vis påverka flickors föreställningar. Föreliggande studie kan dock inte svara på att det förhåller sig

16 Dock bör man beakta att högre andel av de flickor som uppger att deras föräldrar är mycket religiösa och/eller arbetslösa är flickor med utländsk bakgrund. så, men det är en viktig fråga som bör beaktas. Flickor som uppger att deras föräldrar inte arbetar är också mer lojala till en återhållsam syn på föräktenskapliga sexuella relationer. En förklaring kan vara att flickor med mindre materiella resurser har svårare att förverkliga sig själva. Sexualiteten blir därför en tillgång som de kan använda för att skapa sig en position i samhället (jmf Berggren 2001). Bland familjer där normer kring oskuld upprätthålls kan en dotters ärbarhet skapa en fördelaktig förhandlingsposition vid ingåendet av äktenskap (jmf Akpinar 2003, Schlytter 2004). Föräldrar som inte förvärvsarbetar kan också antas ha mer insyn i ungdomars vardag och kan möjligen också påverka deras handlingsutrymme och föreställningar om exempelvis sexualitet. Socioekonomiska bakgrundsfaktorer samvarierar med flickornas föreställningar kring oskuldsnormer. Således kan en del av skillnaderna i föreställningar bland flickor förklaras med socioekonomisk bakgrund än enbart etnisk bakgrund i sig. ${ }^{17}$ Ett annat resultat är att yngre ungdomar i större utsträckning accepterar oskuldsnormer som begränsar flickors sexualitet. En del av förklaringen kan bottna i att yngre ungdomar i större utsträckning saknar egna erfarenheter av sexualitet och att detta kan ha samband med deras föreställningar. Att ålder visar signifikanta samband med påståenden som skildrar begränsningar i flickors sexuella handlingsutrymme och inte pojkars kan även tolkas som att flickor överlag har ett mer begränsad sexuellt handlings-

17 Socioekonomiska bakgrundsfaktorer samvarierar inte i samma utsträckning med pojkars föreställningar. 
utrymme och att begränsningar i större utsträckning gäller yngre flickor.

Tidigare forskning har visat att oskuldkravet i stor utsträckning begränsar flickors föräktenskapliga sexuella möjligheter. Resultatet i denna studie visar att pojkar med utländsk bakgrund värderar oskuldens betydelse strängare för en flicka än för en pojke. Flickor med utländsk bakgrund (och utlandsfödda pojkar) är mer positiva till föräldrars bestämmande när det gäller en dotters sexuella utrymme än en sons. Detta medför som tidigare forskning åskådliggjort konsekvenser för de flickor som förväntas leva upp till dessa krav. Oskuldsnormer har även internaliserats av pojkar i förhållande till deras eget sexuella handlingsutrymme och detta begränsar med största sannolikhet även pojkars sexualitet. Skillnaderna i föreställningar mellan ungdomar födda i Sverige med utlandsfödda föräldrar samt ungdomar som själva är födda utomlands är förhållandevis små. Det finns emellertid mönster som indikerar att flickor födda i Sverige med utlandsfödda föräldrar i större utsträckning tar avstånd från oskuldsnormer än övriga ungdomar med utländsk bakgrund (se längst ner Tabell 4). Ett annat mönster visar att pojkar födda i Sverige med utlandsfödda föräldrar bedömer föräldrars inflytande i oskuldsfrågan ungefär lika för båda könen i jämförelse med pojkar födda utomlands som bedömer frågan striktare när det avser en dotter. Att ungdomar födda utomlands visar en något mer accepterande inställning till normer som begränsar det föräktenskapliga sexuella utrymmet kan vara ett resultat av att det inom gruppen finns en högre andel relativt nyinflyttade individer som invandrat före den ordina- rie skolstarten. Invandringsmönster från slutet av 1990-talet fram tills idag visar att de största grupperna asylsökande har sin bakgrund i länder med en mer traditionell syn på sexualitet (Råbergh 2004). ${ }^{18}$ Ungdomar födda och uppväxta i Sverige kan i sin tur vara mer influerade av samhällets syn på ungdomssexualitet. Resultatet bör dock tolkas med försiktighet eftersom skillnaderna i föreställningar mellan ungdomar födda i Sverige och födda utomlands är förhållandevis små. Det är även viktigt att fästa uppmärksamheten på att inte alla ungdomar med utländsk bakgrund instämmer i traditionella värderingar kring sexualitet och att det finns en liten grupp ungdomar med svensk bakgrund som tvärtom instämmer i traditionella normer kring sexualitet.

Ungdomars attityder påverkar troligtvis även deras beteende kring sexualitet. Internationell forskning har visat att bland ungdomar som lever med oskuldskrav minskar benägenheten att söka information eller erkänna att de saknar kunskaper om sexualitet och preventivmedel (jmf Keys et al. 2006). Ett begränsat sexuellt handlingsutrymme behöver inte ha samband med huruvida den enskilde ungdomen är sexuellt aktiv eller inte. Ungdomar som accepterar föreställningar som kan betraktas ge stöd för en såkallad "oskuldskontext" kan men behöver inte vara i riskzonen för en försämrad sexuell hälsa. Detta är en ytterst angelägen fråga för skolans samlevnadsundervisning. Ungefär var tredje högstadieelev

18 De tio största asylsökande grupperna mellan 1998-2002 kom från Irak, Serbien, Montenegro, Bosnien-Hercegovina, Iran, Ryska federationen, Somalia, Syrien, Afghanistan, och Turkiet. 
med utländsk bakgrund instämmer $i$ att en tjej ska vara oskuld samt att föräldrar får bestämma att en dotter ska vara oskuld vid ingåendet av äktenskap och var femte elev instämmer i motsvarande när det avser en kille/son. Huruvida dessa ungdomar också lever med traditionella värderingar kring sexualitet kan inte denna studie svara på. Skolan måste emellertid våga diskutera oskuldsbegreppet och dess kontextuella sammanhang. Detta inkluderar förutom fundamentalt skilda uppfattningar om sexualitet även begränsningar i ungdomars liv i övrigt. Att få igång ett samtal om kraven på en flickas respektive en pojkes oskuld och diskutera skillnaden mellan mer självvalda beslut och innebörden av att leva med oskuldskrav ökar ungdomars medvetenhet om olika värderingar. Det är även viktigt att diskutera på vilket sätt dessa värderingar påverkar en flicka respektive en pojke. Ungdomar som växer upp med olika normer och ungdomar som exempelvis möter kamrater med ett synsätt som starkt skiljer sig från det som är allmänt etablerat i samhället behöver en plattform där de kan samtala om olikheter.

Normer kring sexualitet ser mycket olika ut i olika samhällen och framförallt är synen på kvinnans sexualitet och lust starkt normerande. Kontroll av sexualitet har genom historien förekommit och förekommer fortfarande i alla samhällen. I vilken utformning och omfattning denna kontroll påverkar enskilda individer och vad som händer när enskilda individer inte erkänner denna kontroll är viktigt att lyfta fram. Internationell forskning visar att "crimes of honour" så kallade "hedersbrott" kan betraktas utifrån familjens/släktens ståndpunkt som ett resultat av misslyckad kontroll av den enskildes sexualitet och inte kontrollen i sig (Abdullahi 2005).

Det finns en grupp ungdomar som svarar att en tjej och/eller en kille ska vara oskuld när äktenskap ingås. Deras svar kan tolkas som att det ger uttryck för ett mer självvalt ställningstagande som kan men inte behöver vara påverkad av familjens/omgivningens förväntningar. Det är rimligt att anta att det inom gruppen ungdomar som dessutom ger föräldrar utrymme att bestämma i oskuldsfrågan kan finns de som i större utsträckning begränsas i sitt sexuella handlingsutrymme. Det är viktigt att uppmärksamma dessa ungdomar och vara medveten om de konsekvenser en eventuell "misslyckad kontroll" av deras sexualitet kan innebära för den enskilde ungdomen (jmf Abdullahi 2005). Att en sexuell relation förväntas ske inom ett äktenskap kan inte direkt jämföras med att en sexuell relation bör begränsas till efter ingåendet av äktenskap. Det senare innebär på grund av dess strukturerade principer en kränkning av ungdomars integritet. "Oskuldskontexten" kännetecknas bland annat av principer som bygger på att sexualiteten trots sin privata uttrycksform betraktas som något "tillgängligt" för andra än individen själv att besluta om. Ungdomssexualiteten som sådan erkänns inte men är högst närvarande i ungdomarnas liv. Det mest avgörande är de könssegregerade principer där ovanstående i större utsträckning tillämpas för en flicka än för en pojke. För att förstå vad en så kallad "oskuldskontext" innebär krävs det att värderingar kring oskuld sätts i ett specifikt sammanhang samtidigt som fokus på helhetsbilden inte glöms bort. Det innebär exempelvis en 
utvidgad definition av oskuldbegreppet som inte begränsas till kontrollen av ungdomars sexualitet utan även inkluderar de föreställningar som upprätthåller och erkänner icke självvalda begränsningar i ungdomars liv. Detta är nyckeln till förståelse av den skillnad som finns mellan ett personligt mer eller mindre självvalt ställningstagande och ett av andra mer eller mindre uttalat krav. Emellertid bör tolkningen av studiens resultat utgå från att föreställningar ger mening åt människors liv och att dessa kan ha olika betydelser. Trots de skiljemönster som finns bland elever med svensk respektive utländsk bakgrund är det även viktigt att beakta det som förenar ungdomarna. Exempelvis ställer sig merparten av ungdomarna kritiska till oskuldsnormer. De ungdomar som instämmer i oskuldsnormer behöver nödvändigtvis inte få traditionella normer kring sexualitet förmedlade till sig. Det är även viktigt att beakta att ungdomar som instämmer i oskuldsnormer kan men behöver inte själva vara begränsade i sitt sexuella handlingsutrymme.

\section{Referenser}

Abdullahi, An-Na'im, A. (2005) „The role of 'community discorse' in combating 'crimes of honour': preliminary assessment and prospects". I L. Welchman \& S. Hossain (red.) Honour. Crimes, paradigms and violence against women. London and New York: Zed Books.

Ahmadi, N. (2003) "Migration challenges views on sexuality". Ethnic and racial studies vol $26 \mathrm{nr} 4$, s. 684-706.

Akpinar, A. (1998) Male's honour and female's shame: gender and ethnic identity constructions among Turkish divorcées in the migration context. Uppsala: Dept. of Sociology.

Akpinar, A. (2003) "The honour/shame complex revisited".Violence against women in the migration context. Womens studies International Forum vol 26 nr 5, s. 425-442.

Ambjörnsson, F. (2004) I en klass för sig: genus, klass och sexualitet bland gymnasietjejer. Stockholm: Ordfront.

Andersson, Å. (2003) Inte samma lika: identifikationer hos tonårsflickor i en multietnisk stadsdel. Eslöv: Symposion.
Awla, R. (2005) "Hedersmord och islam». I K. Johansson (red.) Hedersmord. Tusen år av hederskulturer. Lund: Historiska institutionen vid Lunds universitet och historiska media.

Berg, L. (1999) Lagom är bäst: unga kvinnors berät telser om heterosexuell samvaro och pornografi. Stockholm: Bilda, Riksorganisationen för kvinnojourer i Sverige ROKS.

Berg, M. (1994) Seldas andra bröllop: berättelser om hur det är: turkiska andragenerationsinvandrare, identitet, etnicitet, modernitet, etnologi. Göteborg: Etnologiska institutionen, Göteborgs universitet.

Berggren, I. (2001) Identitet, kön och klass: hur arbetarflickor formar sin identitet. Göteborg: Acta Universitatis Gothoburgensis.

Bäckman, M. (2003) Kön och känsla: samlevnadsundervisning och ungdomars tankar om sexualitet. Göteborg, Stockholm: Makadam.

Callan, V.J. \& Gallois, C. (1985) "Sex-Role Attitudes and Attitudes to Marriage Among Urban Greek-Australian and Anglo-Australian Youth". Journal of Comparative Family Studies 
vol $16 \mathrm{nr} 3$, s. 345-356.

Darvishpour, M. (1993) „En bild av kvinnornas försämrade situation i Iran". Sociologisk Forskning nr 3.

Daugherty, R. L. \& Burger, M.J. (1984) »The Influence of Parents, Church, and Peers on the Sexual Attitudes and Behaviors of College Students". Archives of sexual behavior vol $13 \mathrm{nr}$ 4, s. 351-359.

Delaney, C. (1987) "Seeds of honour. Fields of shame". I D. Gilmore (red.) Honour and shame and the unity of Mediterranean. Washington. DC: American Anthropological Association vol 22 s. 35-48.

Edgardh, K. (1992) Tonåringar - sex och samlevnad. Göteborg: Gothia.

Edgardh, K. (2001) Adolescent sexuality and sexual abuse: a Swedish perspective. Stockholm: Karolinska institutet.

Eldén, Å. (2003) Heder på liv och död: våldsamma berättelser om rykten, oskuld och heder. Uppsala: Acta Universitatis Upsaliensis.

Farahani, F. (2006) "Slöjan är en bärbar mur». Axess 2006:2.

Forsberg, M. (2000) Ungdomar och sexualitet: en kunskapsöversikt år 2000. Stockholm: Folkhälsoinstitutet.

Forsberg, M. (2005) Brunetter och blondiner: om ungdom och sexualitet $i$ det mångkulturella Sverige. Göteborg: Institutionen för socialt arbete, Göteborgs universitet.

Forsberg, M. (2006) Ungdomar och sexualitet: en forskningsöversikt år 2005. Stockholm: Statens folkhälsoinstitut.

Fronk C., Huntington R.L. \& Chadwick B.A.E. (1999) „Expectations for Traditional Family Roles: Palestinian Adolescents in the West Bank and Gaza». Sex Roles, vol. 41 nr 9 - 10, s. 705-735.

Hammarén, N. (2003) "Horor, players och de Andra : Killar och sexualitet i det nya Sverigeu. I T. Johansson (red.) Sexualitetens omvandlingar. Göteborg: Daidalos.

Helmius, G. (1990) Mogen för sex?! Det sexuellt restriktiviserande samhället och ungdomars heterosexuella glädje. Uppsala: Uppsala universitet.
Henriksson, B. \& Lundahl, P. (1993). Ungdom, sexualitet, könsroller: en intervjustudie. Göteborg: Institutionen för socialt arbete, Göteborgs universitet.

Higgins L.T., Zheng M., Liu Y. \& Chun Hui Sun (2002) "Attitudes to Marriage and Sexual Behaviors: A Survey of Gender and Culture Differences in China and United Kingdom" Sex Roles, vol. 46 nr 3-4, s. 75-89.

Högdin, S. (2006) „Var går gränsen? Föräldrars gränssättning avseende ungas deltagande i sociala aktiviteter. En jämförelse utifrån kön och etnicitet«. Sociologisk forskning nr 4 s. 41-65.

Jarlbro, G. (1989) Vad vet vi om svenskarnas sexualvanor? En utvärdering av forskning inom området. Stockholm: Socialdepartementet, AIDS-delegationen.

Jeffner, S. (1997). "Liksom våldtäkt, typ" om betydelsen av kön och heterosexualitet för ungdomars förståelse av våldtäkt. Uppsala: Uppsala universitet.

Jemteborn, A. (2005) "Å Stå På Sig, På Egna Ben» En fallstudie om en flicka $i$ en hederskultur och hennes motstånd mot att inordna sig efter släktens krav. Stockholm: Institutionen för socialt arbete, Socialhögskolan, Stockholms universitet.

Keys D., Rosenthal D. \& Pitts M. (2006) "Young People, Sexual Practice and Meanings». I. P. Aggleton, A. Ball \& P. Mane. (red.) Sex, drugs and young people. International perspectives. London and New York: Routledge.

Khader, N. (1998) Familjeliv och levnadsmönster bland Mellanösterns muslimer. Stockholm: Wahlström \& Widstrand.

Lagerberg, D. \& Sundelin, C. (2000) Risk och prognos $i$ socialt arbete med barn. Forskningsmetoder och resultat. Stockholm: Gothia/CUS.

Lewin, B. (1991). Att omplantera sexualiteten: om latinamerikanska ungdomars sexuella socialisation i Sverige. Uppsala: Sociologiska institutionen, Uppsala universitet.

Lewin, B. \& Fugl-Meyer, K. (1998). Sex i Sverige: om sexuallivet $i$ Sverige 1996. Stockholm: Folkhälsoinstitutet.

Länsstyrelsen (2002) Rätten till sitt eget liv. Länsstyrelsen i Stockholms län. Rapport 2002:13. 
Länsstyrelsen (2004) Utsatta flickor i patriarkala familjer. Länsstyrelsen i Västra Götaland. Rapport 2004:4.

Lööf, C. \& Folkhälsoinsitutet. (1999). Det handlar om personer - inte om kulturer! : sex- och samlevnadsundervisningen i mångkulturella skolor. Stockholm: Folkhälsoinstitutet.

Mørck, Y. (2000). »Hyphenated Danes : Contested fields of Gender, Generation and Ethnicity». Young Vol $8 \mathrm{nr} 3$.

Okazaki, S. (2002). »Influences of Culture on Asian Americans' Sexuality". Journal of sex research, vol $39 \mathrm{nr}$ 1, s. 34.

Okin, S.M. (2002) Mångkulturalism - kvinnor $i$ kläm? Göteborg: Daidalos.

Persson, J. (2003). „Värt att vänta på? Om frikyrkoungdomars syn på sexualitetu. I T. Johansson \& P. Lalander (red.) Sexualitetens omvandlingar. Politisk lesbiskhet, unga kristna och machokulturer. Göteborg: Daidalos.

Prieur, A. (2004) Balansekunstner. Betydningen av innvandrerbakgrunn i Norge. Oslo: Pax forlag.

Råbergh, C. (2004) Oviss väntan. Equal Svenska
EFS-Rådet. www.temaasyl.se

Salam Abdul, S. (2005) "Centre for Egyptian women's legal assistance,'Crimes of honour' as violence against women in Egypt«. I L. Welchman \& S. Hossain (red.) Honour. Crimes, paradigms and violence against women. London and New York: Zed Books.

SCB (1982) Socioekonomisk indelning. SEI. Stockholm: Statistiska centralbyrån.

Schlytter, A. (2004). Rätten att själv få välja: arrangerade äktenskap, kön och socialt arbete. Lund: Studentlitteratur.

Skeggs, B. (2000) Att bli respektabel. Konstruktioner av klass och kön. Göteborg: Daidalos.

Wikan, U. (2005) »Hederskulturen vill kontrollera privatlivet och dölja det för insyn «. Stockholm: Axess vol. $4 \mathrm{nr} 1 \mathrm{s.} 21-23$.

Wikan, U. \& Mitchell, C. (2005). En fråga om heder. Ny utg. edn. Stockholm: Ordfront.

Zetterberg, H.L. (1969) Om sexuallivet $i$ Sverige. Värderingar, normer, beteenden i sociologisk tolkning. Stockholm: Utbildningsdepartementet.

\section{Summary}

\section{Attitudes towards premarital sex and the loss of virginity. A study amongst boys and girls}

This study examines a survey carried out amongst 1,193 senior-level students of the Swedish nine-year compulsory school. Questions such as attitudes towards premarital sex and the loss of virginity before marriage are raised in this study. The aim of this study is to examine the appropriation of sexuality within the context of marriage as well as the students' attitudes towards family restraint regarding the individual's premarital sexuality. Swedish adolescents with immigrant background are more likely to demonstrate conservative attitudes towards premarital sex and are more likely to tolerate parental restraint than others. The results also illustrate that sex and ethnicity do not interact in determining subject responses. Boys and girls with immigrant backgrounds are more likely to show traditional attitudes towards prema- 
rital sex and are also more likely to accept parental authority concerning the sexual conduct of girls. Other significant findings show that girls with religious and/or loweducated parents have more restrictive attitudes towards premarital sex.

Sex is an important part of life, and premarital sex is an issue young people have to face. Other studies have shown that families who emphasize honour and chastity are more likely to control teenage girls' sexua- lity, which also often extends to restraining or limiting their social relations (Andersson 2003). Young people with a conservative attitude towards premarital sex were more likely not to use contraceptives while engaging in sexual intercourse (Keys et al. 2006). Traditional attitudes and the impact of these attitudes in relation to adolescent sexuality are questions that are examined in this study. 